\title{
Effects of miR-21 on proliferation and apoptosis in human gastric adenocarcinoma cells
}

\author{
JUN-BAO GU, XUE-BIN BAO and ZHAO MA \\ Department of Gastrointestinal Surgery, Henan Provincial People's Hospital, Zhengzhou, Henan 450003, P.R. China
}

Received October 17, 2016; Accepted March 14, 2017

DOI: $10.3892 / \mathrm{ol} .2017 .6171$

\begin{abstract}
The present study investigated the expression of miR-21 in MGC803 gastric cancer cells and its effects on Bcl-2 expression and cell proliferation, apoptosis, and invasion. In total 50 patients were recruited with gastric cancer who were admitted to the Henan Province People's Hospital. The samples of gastric cancer and the adjacent normal tissues were collected after surgery. We found that mRNA levels of $m i R-21$ and $B c l-2$ were significantly elevated in tumor tissues compared to control tissue. The expression of Bcl-2 protein was also elevated in cancerous tissue. This high expression of Bcl-2 was associated with clinical stage, lymph node metastasis, and tumor differentiation degree. Inhibition of miR-21 reduced the levels of $m i R-21$ and $\mathrm{Bcl}-2$ in MGC803 cells, and lowered cell proliferation and invasiveness. These results indicate that miR-21 and $\mathrm{Bcl}-2$ may participate in the occurrence and development of gastric adenocarcinoma, suggesting their potential role as biomarkers and therapeutic targets.
\end{abstract}

\section{Introduction}

The incidence of gastric cancer in the digestive tract is $13.9 \%$ with a continuous increasing trend (1). The complex pathogenesis of cancer involves oncogene activation, mutation of tumor suppressor genes, and proliferation of malignant cells. In addition, apoptosis is inhibited in the malignant cells (2). The deregulation of proliferation and/or apoptosis induces the appearance of malignant tumors (3). MicroRNAs (miRs) are non-coding RNAs that control gene expression. A recent study confirmed that the development of malignant tumors is highly related to the activation and expression of specific miRs (4). Abnormal expression of miRs can contribute to the dysregulation of oncogenes or tumor suppressor genes, exerting a tremendous influence on the development of malignant tumors and the progression of cancers (5). Investigating miRs can contribute to understanding the

Correspondence to: Dr Jun-Bao Gu, Department of Gastrointestinal Surgery, Henan Provincial People's Hospital, 7 Weiwu Road, Zhengzhou, Henan 450003, P.R. China

E-mail: gujunbao0824@163.com

Key words: miR-21, gastric adenocarcinoma mechanism of proliferation, apoptosis, invasion, and metastasis of gastric cancer cells, and have the potential to become alternative therapeutic targets. Previous findings verified the abnormal expression of miRs in gastric cancer tissues $(5,6)$. Thus, specific miRs can be used as markers to distinguish normal and malignant tissues, with the potential to become promising targets for testing, diagnosing, and treating gastric cancer $(7,8)$.

Bcl-2 is an anti-apoptotic gene located on human chromosome 18q21 (9) highly expressed in stem cells of human tissues, including skin basal collagen cells and small intestinal crypt bottom cells. By inhibiting cell apoptosis, Bcl-2 ensures that the cells have sufficient time to complete their transformation from stem cells into highly differentiated cells (10). Previous results have verified that $\mathrm{Bcl}-2$ is closely related to the occurrence and development of lymphoma, colorectal, breast, cervical, and thyroid cancer (11-13). Other studies demonstrate that $\mathrm{Bcl}-2$ is also linked to the prognosis of certain tumors (14). In addition, a high expression of $\mathrm{Bcl}-2$ is closely associated with the invasion and metastasis of malignant tumor cells and recent studies showed that the expression of Bcl-2 in tumor cells can be inhibited by artificial methods, leading to the increase of cancer cell sensitivity to chemotherapeutic drugs (15). In addition, we downregulation of Bcl-2 induces and speeds apoptosis in primary tumor cells.

We further investigated the role of miR-21 in the occurrence and development of gastric cancers by analyzing gastric cancer pathology and adjacent normal tissues. We examined the potential mechanisms of miR-21 to provide a novel biomarker for early diagnosis and provide a rationale for new treatments of gastric cancer.

\section{Materials and methods}

Tissue processing. Gastric carcinoma and the corresponding normal gastric tissue were stored at $-80^{\circ} \mathrm{C}$. The samples were ground and the powder was placed in a pre-processed tube, adding $500 \mu \mathrm{l}$ TRIzol, and mixed for $15 \mathrm{sec}$; $170 \mu \mathrm{l}$ chloroform was added with $15 \mathrm{sec}$ mixing and centrifugation at $10,000 \times \mathrm{g}$ for $10 \mathrm{~min}$. Supernatant $(400 \mu \mathrm{l})$ was added to a new tube, $500 \mu \mathrm{l}$ isopropanol was added with $15 \mathrm{sec}$ mixing with the vortex, then centrifuge at $10,000 \mathrm{x}$ g for $10 \mathrm{~min}$ at $4^{\circ} \mathrm{C}$. Supernatant was discard, the white sediment at the bottom of the tube was air dried. Total RNA was dissolved in $50 \mu \mathrm{l}$ DEPC water. 
Western blot analysis. Two hundred milligrams of tissue was sheared and $1 \mathrm{ml}$ of lysate was added; homogenated and centrifuged at 6,200 x $\mathrm{g}$ for $10 \mathrm{~min}$, the supernatant was transferred to a new tube; centrifuge at $10,000 \mathrm{x} \mathrm{g}$ for $60 \mathrm{~min}$, and the supernatant was transferred to a new tube. The protein content was determined with the protein kit $\mathrm{BCA}^{\mathrm{TM}}$.

Flow cytometry. The MGC803 human gastric cancer cell line was transfected with miR-21, after which the cells were starved for $48 \mathrm{~h}$ after transfection. Then, we trypsinized the cells $(0.25 \%$ trypsin) into a single cell suspension and used Annexin V-FITC/PI to detect apoptosis by cytometer. Primer sequences used were: miR-21 forward, 5'-TCCGAAGTTGTA GTCAGACT-3' and reverse, 5'-GTGCAGGGTCCGAGGT-3'.

MTT assay. MGC803 cells transfected with miR-21 were trypsinized and re-suspended in Dulbecco's modified Eagle's medium (DMEM) culture medium containing $10 \%$ fetal bovine serum (FBS). The cells were seeded in 96-well culture plates with a volume of $200 \mu \mathrm{l}$ per well. The 96-well culture plates were placed in $5 \% \mathrm{CO}_{2}$ cell culture incubator with saturated humidity and $37^{\circ} \mathrm{C}$ for 3-5 days. MTT solution $(20 \mu \mathrm{l})$ was then added to each well, and the cells were incubated in the incubator for $4 \mathrm{~h}$. The culture medium was discarded, $150 \mu \mathrm{l}$ DMSO was added per well, and shaken for $10 \mathrm{~min}$. Absorbance was measured at $92 \mathrm{~nm}$ in the cell culture medium using enzymelinked immunosorbent assay, and the cell growth curve was drawn with the time as the horizontal coordinate. The DMEM (FBS-free) was used to dilute the Matrigel. MGC803 cells were cultured with serum-free DMEM for $24 \mathrm{~h}$. The supernatant was used as the chemotaxis solution with $0.05-0.2 \%$ BSA. MGC803 cells were washed with PBS 2-3 times. Cell culture medium (DMEM-free) was added and the cells were placed in the incubator for $24 \mathrm{~h}$. The supernatant was discarded and digested with $0.25 \%$ trypsin. The supernatant was discarded, and DMEM with 5\% BSA was used to re-suspend cells; $300 \mu \mathrm{l}$ DMEM (FBS-free) was added to the upper chamber; $200 \mu 1$ chemotaxis solution was added to the lower chamber, and the Matrigel was covered; $400 \mu \mathrm{l}$ cell suspension was added to the upper chamber and incubated for $48 \mathrm{~h}$; $95 \%$ ethanol was used for $30 \mathrm{~min}$ and then stained with $\mathrm{H} \& \mathrm{E}$. Five fields of view were selected to count and take the average value of the transmembrane cells. The above experiments were repeated three times.

\section{Results}

Levels of miR-21 and Bcl-2 mRNA in gastric cancer and adjacent normal tissue. To examine the role of miR-21 and $\mathrm{Bcl}-2$ in gastric cancer, we extracted total RNA from gastric cancer samples and adjacent normal tissue to measure mRNA levels. We measured mRNA levels of $m i R-21$ and $B c l-2$ by fluorescent quantitative PCR in 50 pairs of gastric cancer tissues and the adjacent normal tissues (Tables I and II). The $\Delta \mathrm{CT}$ values for $m i R-21$ in the gastric cancer group were significantly higher than those in the control group (Table I). In addition, the $\Delta C T$ values for $B c l-2$ mRNA in the gastric cancer group was also significantly higher that in the control group (Table II).

Expression of Bcl-2 in gastric cancer. We next validated the elevated $\mathrm{Bcl}-2$ mRNA expression by analyzing the protein
Table I. Expression of miR-21 mRNA (mean $\pm \mathrm{SD}, \mathrm{n}=50$ ).

\begin{tabular}{lccc}
\hline Groups & $\Delta \mathrm{Cq}$ & $\Delta \Delta \mathrm{Cq}$ & $2^{-\Delta \Delta \mathrm{Cq}}$ \\
\hline Para-gastric cancer & $14.78 \pm 0.15$ & $6.69 \pm 0.32$ & $1.06 \pm 0.13$ \\
Gastric cancer tissues & $8.63 \pm 0.26$ & $0.54 \pm 0.12$ & $8.12 \pm 0.21^{\text {a }}$
\end{tabular}

${ }^{\mathrm{a}} \mathrm{P}<0.01$, as compared the experimental and control group.

Table II. Expression of Bcl-2 mRNA (mean $\pm \mathrm{SD}, \mathrm{n}=50$ ).

\begin{tabular}{lrcc}
\hline Groups & $\Delta \mathrm{Cq}$ & $\Delta \Delta \mathrm{Cq}$ & $2^{-\Delta \Delta \mathrm{Cq}}$ \\
\hline Gastric cancer & $12.18 \pm 0.15$ & $7.81 \pm 0.19$ & $1.13 \pm 0.55$ \\
Para-gastric cancer & $5.63 \pm 0.26$ & $0.43 \pm 0.27$ & $9.26 \pm 0.37^{\mathrm{a}}$
\end{tabular}

${ }^{\text {a }}<0.01$, as compared the experimental and control group.

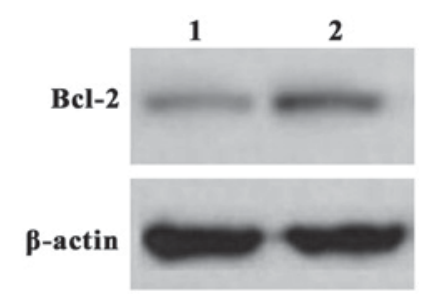

Figure 1. Expression of Bcl-2 proteins in normal and tumor tissues.

levels. The expression of $\mathrm{Bcl}-2$ in the gastric cancer and control group were measured and tested by western blot analysis. Compared to the control group, the level of the $\mathrm{Bcl}-2$ protein in the gastric cancer group was significantly higher (Fig. 1), supporting the results with mRNA levels.

Correlation of Bcl-2 expression and clinical features. We investigated the correlation between $\mathrm{Bcl}-2$ protein expression in gastric adenocarcinoma and clinical features (Table III). Expression of $\mathrm{Bcl}-2$ protein was not associated to age and locations of the tumor. However, we found a strong association with the tumor clinical stage, tumor cell invasion of lymph nodes, and the tumor metastasis degree (Table III). We also compared the relative expression of miR-21 and Blc- 2 mRNA by Spearman test. We found a strong correlation of the expression of miR-21 and Blc-2 mRNA.

Inhibition of miR-21 in MGC803 cells. To investigate the functional relevance of miR-21 expression in gastric adenocarcinoma, we introduced the miR-21 inhibitor into MGC803 cells and normal cells. We measured the expression levels of miR-21 after $48 \mathrm{~h}$. Compared to normal cells, the expression of miR-21 in MGC803 cells was significantly reduced (Fig. 2).

The Protein expression of Bcl-2 in MGC803 lineage and normal cells. We examined Bcl-2 expression, cell proliferation, apoptosis and invasion on MGC803 cells treated with miR-21. We found that miR-21 inhibition resulted in significantly lower levels of Bcl-2 protein (Table IV). 
Table III. Bcl-2 protein expression and the clinical features.

\begin{tabular}{|c|c|c|c|c|}
\hline Group & $\begin{array}{l}\text { Cases } \\
(\mathrm{n})\end{array}$ & $\begin{array}{c}\text { High } \\
\text { Bcl-2 (n) }\end{array}$ & $\begin{array}{c}\text { Low } \\
\text { Bcl-2 (n) }\end{array}$ & $\mathrm{P}$-value \\
\hline Age (years) & & & & 0.72 \\
\hline$\leq 65$ & 14 & 8 & 6 & \\
\hline$>65$ & 36 & 18 & 18 & \\
\hline Clinical stages & & & & 0.024 \\
\hline $\mathrm{T} 1$ & 14 & 3 & 11 & \\
\hline $\mathrm{T} 2$ & 20 & 8 & 12 & \\
\hline $\mathrm{T} 3$ & 10 & 8 & 2 & \\
\hline $\mathrm{T} 4$ & 6 & 5 & 1 & \\
\hline Lymph nodes & & & & 0.025 \\
\hline Yes & 9 & 8 & 1 & \\
\hline No & 41 & 13 & 28 & \\
\hline Metastasis degree & & & & 0.041 \\
\hline High & 21 & 18 & 3 & \\
\hline Middle & 16 & 10 & 6 & \\
\hline Low & 11 & 4 & 7 & \\
\hline Tumor location & & & & 0.701 \\
\hline $\begin{array}{l}\text { Before cardiac } \\
\text { stomach }\end{array}$ & 15 & 7 & 8 & \\
\hline $\begin{array}{l}\text { After cardiac } \\
\text { stomach }\end{array}$ & 4 & 1 & 3 & \\
\hline $\begin{array}{l}\text { On cardiac } \\
\text { stomach }\end{array}$ & 31 & 17 & 14 & \\
\hline
\end{tabular}

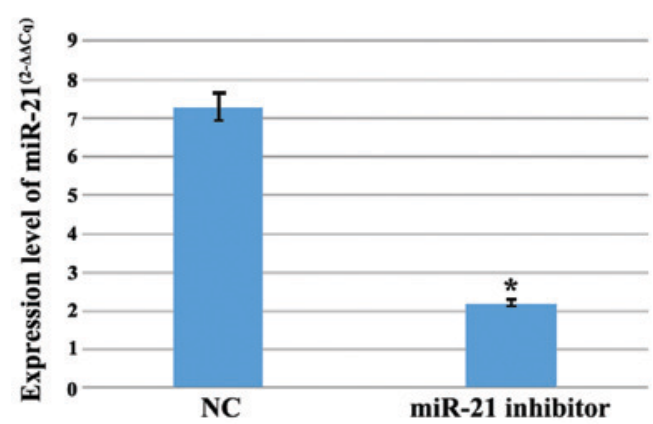

Figure 2. Expressional level of miR-21 in MGC803 after transfer with miR-21 inhibitor. ${ }^{*} \mathrm{P}<0.01$.

Proliferation of MGC803 after miR-21 inhibition. The proliferation of the MGC803 cells using the MMT assay was determined. We incubated normal and MGC803 cells for 24, 48 and $72 \mathrm{~h}$ with miR-21 inhibitor found at each time-point the proliferation of the MGC803 cells was decreased compared to the control group (Fig. 3). At each time-point the differences were statistically significance $(\mathrm{P}<0.01)$.

Apoptosis in MGC803 cells after miR-21 inhibition. To further investigate the effects of miR-21 in MGC803 apoptosis, we used Annexin V-FITC/PI double stain. We evaluated MGC803 apoptosis at different time-points (0, 24, 48, 72 and $96 \mathrm{~h}$ ) after miR-21 inhibition. As time progressed, MGC803 apoptosis showed acceleration (Fig. 4). At each
Table IV. The protein expression of Bcl-2 in MGC803 lineage and normal cells.

\begin{tabular}{lcccccc}
\hline & & \multicolumn{2}{c}{ Bcl-2 } & & & \\
\cline { 3 - 5 } Groups & $\mathrm{n}$ & + & - & $\begin{array}{c}\text { Positive } \\
\text { rate }(\%)\end{array}$ & $\chi^{2}$ & P-value \\
\hline $\begin{array}{l}\text { Gastric } \\
\text { cancer } \\
\text { Control }\end{array}$ & 96 & 35 & 61 & 36.5 & 63.548 & $<0.001$ \\
\hline
\end{tabular}

$\mathrm{P}<0.01$, as compared the experimental and control group.

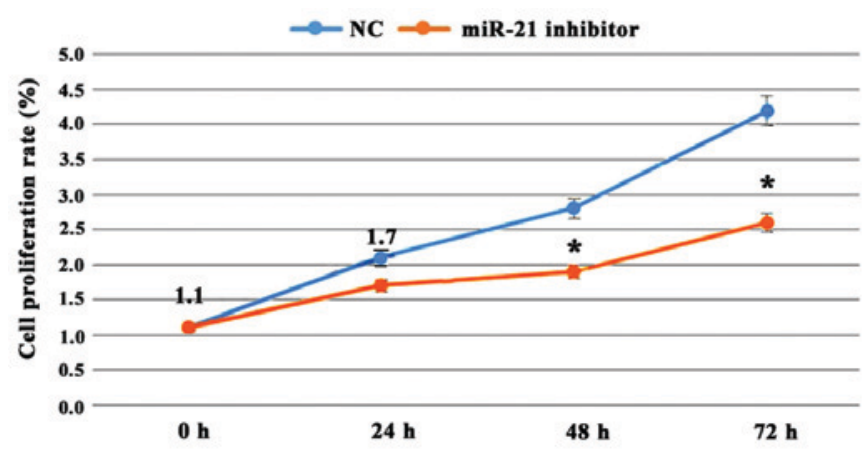

Figure 3. Proliferation of the MGC803 after transferred with miR-21 inhibitor compared to normal cells. ${ }^{*} \mathrm{P}<0.01$.

time-point, the apoptosis of the MGC803 cells was higher than that in normal cells (Fig. 4).

Invasion of MGC803 cells after miR-21 inhibition. The cell invasion ability is one of the key features of tumors, which can represent the malignancy degree of the tumor. To investigate gastric cancer cell invasion, the Transwell assay was used to evaluate the ability of MGC803 to invade after miR-21 inhibition. Compared with the control group, the invasion ability of the MGC803 was significantly decreased $(\mathrm{P}<0.01)($ Fig. 5).

\section{Discussion}

The rapid development of molecular biology and modern cancer medicine has revealed the correlation between miR expression and the development of malignant tumors. miRs can regulate the expression of one third of genes in the human genome and have been shown to exert many physiological functions in cell development, proliferation, differentiation, apoptosis, and metastasis. The expression levels of miRs are altered changed (increased or decreased) in most malignant tumor tissues compared to normal tissues, suggesting strong connection between miRs and the development of tumors (16-20). The malignant tumor growth, proliferation, invasion, and metastasis, and apoptosis are closely correlated to abnormal expression of miRs and its aberrant regulatory activities.

Our experiments show that miR-21 mRNA and $B c l-2$ mRNAs were significantly elevated in gastric adenocarcinoma and miR-21 inhibition reduced the proliferation and increase the apoptosis of MGC803 cells. Antisense inhibition of 

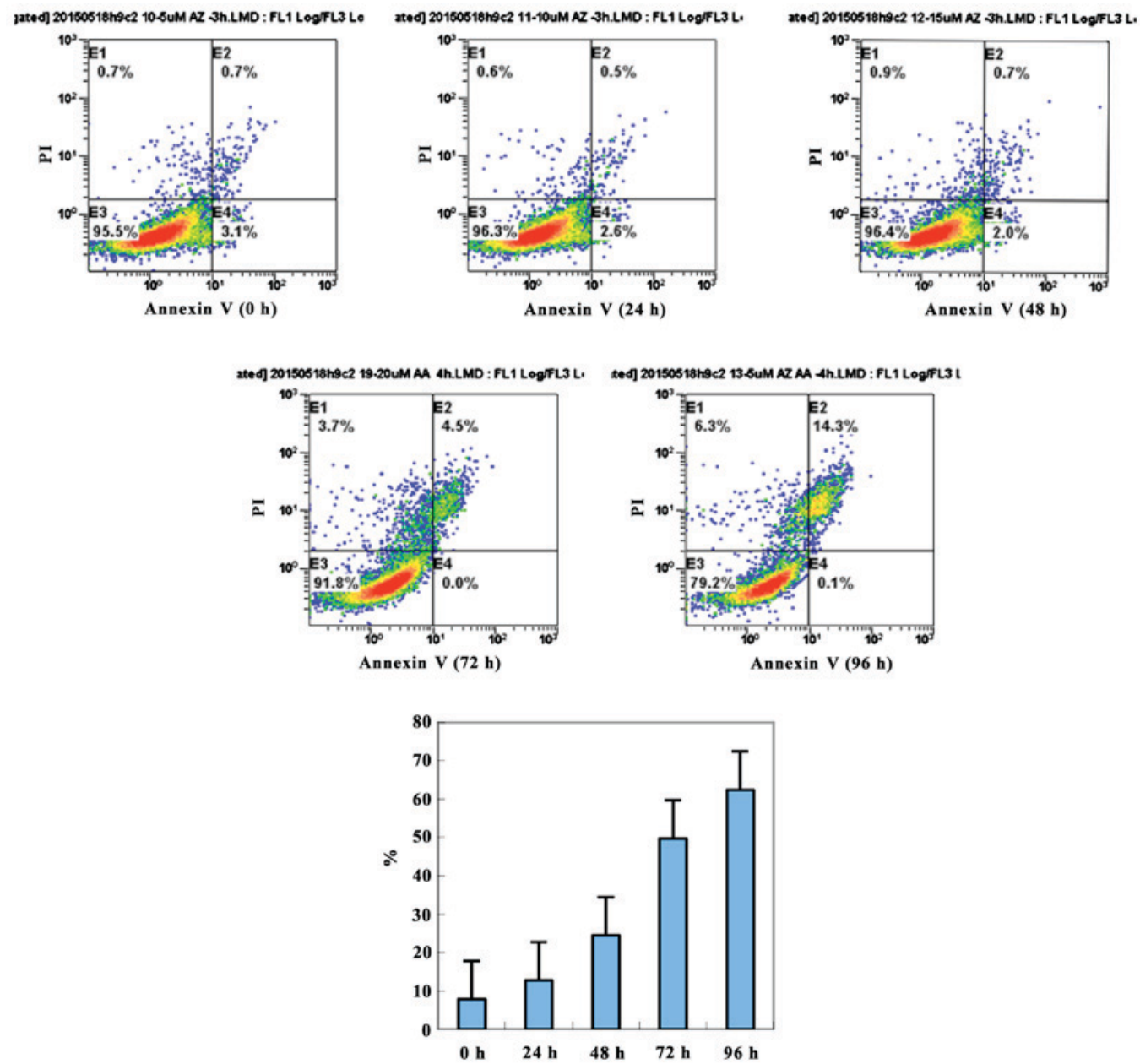

Figure 4. Annexin V-FITC/PI double stain and F were performed to evaluate the conditions of MGC803 cell apoptosis in different time-points $(0,24,48,72$ and $96 \mathrm{~h}$, respectively). As the time elapses, the apoptosis of the MGC803 process was accelerated. At each time-point, apoptosis of the MGC803 cells is higher in the experimental group comparing the normal cells group $(\mathrm{P}<0.05)$.

$\mathbf{A}$

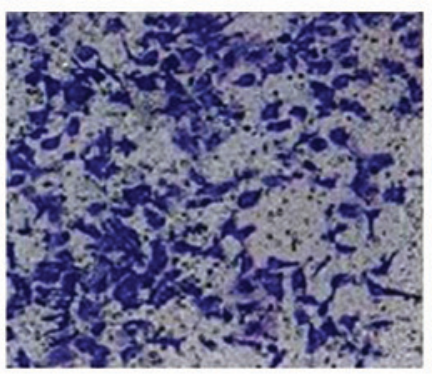

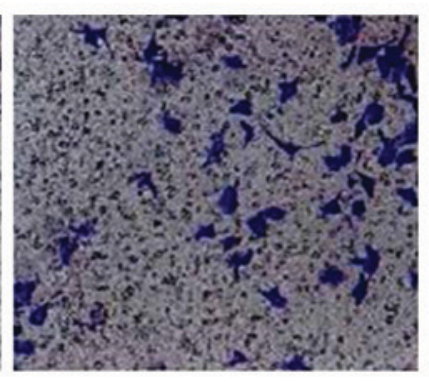

B

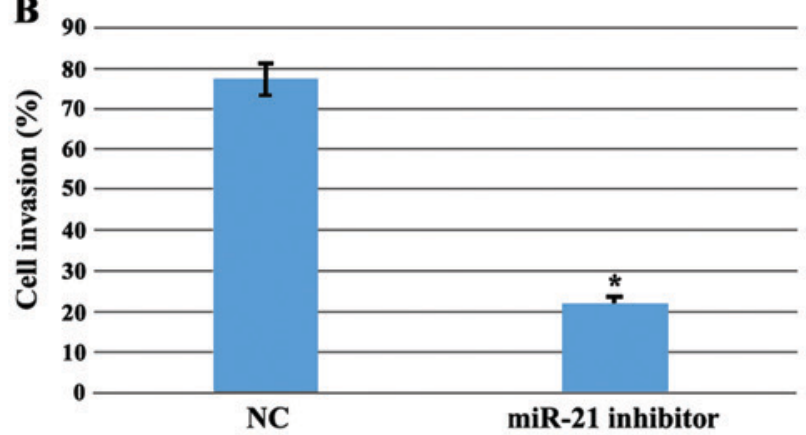

Figure 5. The invasion ability of the MGC803 cells after transferred with miR-21 inhibitor. "P<0.01.

miR-21 can activate malignant cells apoptosis (21). The study of antisense oligonucleotides decreased the expression of miR-21 in glioma cells and cell number, while the activity of caspase-3 and -7 were significantly increased. Our experiments show that miR-21 inhibition had similar effects on gastric adenocarcinoma. The inhibitory effect of Bcl-2 on apoptosis mainly form channel protein in three steps (22-25): i) Increase cell membrane permeability to inhibit the release of mitochondrial apoptotic proteins, and ultimately inhibit apoptosis; ii) improve cellular antioxidant, scavenging oxygen free radicals to suppress apoptosis; and iii) block calcium ion transmembrane flow through intracellular calcium ion concentration regulation to inhibit apoptosis.

Using artificial approaches to inhibit the miR-21 in cholangiocarcinoma cells showed that miR-21 promoted the effectiveness of the chemotherapy drug gemcitabine by inducing apoptosis (26). This suggests that miR-21 activates the PI3K signaling pathway. Lund et al (27) showed that miR-21 can reduce the expression of PDCD4 in breast cancer cells, thus promoting the transformation of tumor cells. In 
colon cancer samples and cell lines, miR-21 can regulate the target gene of PDCD4, thus, suggesting a key role in growth and invasion.

Our study also found that Bcl-2 was associated with clinical staging, lymph node metastasis, and tumor differentiation. The relative expression of $m i R-21$ and $B c l-2$ mRNA were strongly correlated with gastric cancer. Other research found that the content of miR-21 in breast cancer tissue was significantly higher than in normal tissue $(28,29)$. miR-21 was also associated with tumor clinical stage, vascular invasion, and tumor cell proliferation, suggesting a similar role for miR-21 in breast and gastric cancer. A study found that the apoptosis induced factor of PDCD4 inhibits the expression of miR-21 in MCF-7 cells, and miR-21 can play an antagonistic role to p53 apoptosis pathway by inhibition of the tumor suppressor protein p53 (30). Finally, we found that miR-21 promotes the expression of $\mathrm{Bcl}-2$ protein, and miR-21 inhibition decreased cell proliferation. The mechanisms regulating miR-21 high expression in gastric adenocarcinoma tissues are still unclear. One possibility is that miR-21 promotes the proliferation and invasion of human MGC803 cells and the inhibition of apoptosis.

In conclusion, our study reports higher levels of miR-21 in gastric adenocarcinoma, and we discuss the possible role of miR-21 in regulating MGC803 cell apoptosis. Our study supports the potential for miR-21 as a marker for early diagnosis and target treatment for gastric adenocarcinoma.

\section{References}

1. Lee JH, Kim JG, Jung HK, Kim JH, Jeong WK, Jeon TJ, Kim JM, Kim YI, Ryu KW, Kong SH, et al: Clinical practice guidelines for gastric cancer in Korea: An evidence-based approach. J Gastric Cancer 14: 87-104, 2014.

2. Long ZW, Yu HM, Wang YN, Liu D, Chen YZ, Zhao YX and Bai L: Association of IL-17 polymorphisms with gastric cancer risk in Asian populations. World J Gastroenterol 21: 5707-5718, 2015

3. Chen XZ, Chen H, Castro FA, Hu JK and Brenner H: Epstein-Barr virus infection and gastric cancer: a systematic review. Medicine (Baltimore) 94: e792, 2015.

4. Kanaan Z, Rai SN, Eichenberger MR, Roberts H, Keskey B, Pan J and Galandiuk S: Plasma miR-21: a potential diagnostic marker of colorectal cancer. Ann Surg 256: 544-551, 2012.

5. Li T, Li RS, Li YH, Zhong S, Chen YY, Zhang CM, Hu MM and Shen ZJ: miR-21 as an independent biochemical recurrence predictor and potential therapeutic target for prostate cancer. J Urol 187: 1466-1472, 2012.

6. Liu XG, Zhu WY, Huang YY, Ma LN, Zhou SQ, Wang YK, Zeng F, Zhou JH and Zhang YK: High expression of serum miR-21 and tumor miR-200c associated with poor prognosis in patients with lung cancer. Med Oncol 29: 618-626, 2012.

7. Han M, Wang Y, Liu M, Bi X, Bao J, Zeng N, Zhu Z, Mo Z, $\mathrm{Wu} \mathrm{C}$ and Chen $\mathrm{X}$ : MiR-21 regulates epithelial-mesenchymal transition phenotype and hypoxia-inducible factor-1 $\alpha$ expression in third-sphere forming breast cancer stem cell-like cells. Cancer Sci 103: 1058-1064, 2012.

8. Lakomy R, Sana J, Hankeova S, Fadrus P, Kren L, Lzicarova E, Svoboda M, Dolezelova H, Smrcka M, Vyzula R, et al: MiR-195, miR-196b, miR-181c, miR-21 expression levels and $O$-6-methylguanine-DNA methyltransferase methylation status are associated with clinical outcome in glioblastoma patients. Cancer Sci 102: 2186-2190, 2011.

9. Lu QL, Abel P, Foster CS and Lalani EN: bcl-2: role in epithelial differentiation and oncogenesis. Hum Pathol 27: 102-110, 1996.

10. Luanpitpong S, Chanvorachote P, Stehlik C, Tse W, Callery PS, Wang L and Rojanasakul Y: Regulation of apoptosis by Bcl-2 cysteine oxidation in human lung epithelial cells. Mol Biol Cell 24: 858-869, 2013.

11. Flangea C, Potencz E, Mihăescu R, Gîju S and Anghel A: Bcl-2 expression in Hodgkin's lymphoma progression. Rom J Morphol Embryol 49: 357-363, 2008.
12. Manne U, Weiss HL and Grizzle WE: Bcl-2 expression is associated with improved prognosis in patients with distal colorectal adenocarcinomas. Int J Cancer 89: 423-430, 2000.

13. Zhou XL and Wang M: Expression levels of survivin, Bcl-2, and KAI1 proteins in cervical cancer and their correlation with metastasis. Genet Mol Res 14: 17059-17067, 2015.

14. Hajnóczky G, Csordás G, Das S, Garcia-Perez C, Saotome M, Sinha Roy S and Yi M: Mitochondrial calcium signalling and cell death: approaches for assessing the role of mitochondrial $\mathrm{Ca}^{2+}$ uptake in apoptosis. Cell Calcium 40: 553-560, 2006.

15. Shimamoto $S$, Tsuchiya $M$, Yamaguchi F, Kubota $Y$, Tokumitsu $\mathrm{H}$ and Kobayashi R: $\mathrm{Ca}^{2+} / \mathrm{S} 100$ proteins inhibit the interaction of FKBP38 with Bcl-2 and Hsp90. Biochem J 458: 141-152, 2014.

16. Li Y, Yimamu M, Wang X, Zhang X, Mao M, Fu L, Aisimitula A, Nie Y and Huang Q: Addition of rituximab to a CEOP regimen improved the outcome in the treatment of non-germinal center immunophenotype diffuse large B cell lymphoma cells with high Bcl-2 expression. Int J Hematol 99: 79-86, 2014.

17. Simsek EN and Uysal T: In vitro investigation of cytotoxic and apoptotic effects of Cynara L. species in colorectal cancer cells. Asian Pac J Cancer Prev 14: 6791-6795, 2013.

18. Luo KW, Ko CH, Yue GGL, Lee JK, Li KK, Lee M, Li G, Fung KP, Leung PC and Lau CB: Green tea (Camellia sinensis) extract inhibits both the metastasis and osteolytic components of mammary cancer 4T1 lesions in mice. J Nutr Biochem 25: 395-403, 2014.

19. Hu CJ, Zhou L and Cai Y: Dihydroartemisinin induces apoptosis of cervical cancer cells via upregulation of RKIP and downregulation of bcl-2. Cancer Biol Ther 15: 279-288, 2014.

20. Pushkarev VM, Kovzun OI, Pushkarev VV and Tronko M: Biochemical effects of combined action of $\gamma$-irradiation and paclitaxel on anaplastic thyroid cancer cells. Ukr Biokhim Zh (1999) 85: 51-61, 2013.

21. Banzhaf-Strathmann J and Edbauer D: Good guy or bad guy: the opposing roles of microRNA $125 \mathrm{~b}$ in cancer. Cell Commun Signal 12: 30, 2014.

22. Lim L, Balakrishnan A, Huskey N, Jones KD, Jodari M, Ng R, Song G, Riordan J, Anderton B, Cheung ST, et al: MicroRNA-494 within an oncogenic microRNA megacluster regulates G1/S transition in liver tumorigenesis through suppression of mutated in colorectal cancer. Hepatology 59: 202-215, 2014.

23. Melo SA, Sugimoto H, O'Connell JT, Kato N, Villanueva A, Vidal A, Qiu L, Vitkin E, Perelman LT, Melo CA, et al: Cancer exosomes perform cell-independent microRNA biogenesis and promote tumorigenesis. Cancer Cell 26: 707-721, 2014.

24. Kasinski AL, Kelnar K, Stahlhut C, Orellana E, Zhao J, Shimer E, Dysart S, Chen X, Bader AG and Slack FJ: A combinatorial microRNA therapeutics approach to suppressing non-small cell lung cancer. Oncogene 34: 3547-3555, 2015.

25. Chan JA, Krichevsky AM and Kosik KS: MicroRNA-21 is an antiapoptotic factor in human glioblastoma cells. Cancer Res 65: 6029-6033, 2005.

26. Meng F, Henson R, Lang M, Wehbe H, Maheshwari S, Mendell JT, Jiang J, Schmittgen TD and Patel T: Involvement of human micro-RNA in growth and response to chemotherapy in human cholangiocarcinoma cell lines. Gastroenterology 130: 2113-2129, 2006.

27. Lund E, Güttinger S, Calado A, Dahlberg JE and Kutay U: Nuclear export of microRNA precursors. Science 303: 95-98, 2004.

28. Asangani IA, Rasheed SAK, Nikolova DA, Leupold JH, Colburn NH, Post S and Allgayer H: MicroRNA-21 (miR-21) post-transcriptionally downregulates tumor suppressor Pdcd4 and stimulates invasion, intravasation and metastasis in colorectal cancer. Oncogene 27: 2128-2136, 2008.

29. Iorio MV, Ferracin M, Liu CG, Veronese A, Spizzo R, Sabbioni S, Magri E, Pedriali M, Fabbri M, Campiglio M, et al: MicroRNA gene expression deregulation in human breast cancer. Cancer Res 65: 7065-7070, 2005.

30. Frankel LB, Christoffersen NR, Jacobsen A, Lindow M, Krogh A and Lund AH: Programmed cell death 4 (PDCD4) is an important functional target of the microRNA miR-21 in breast cancer cells. J Biol Chem 283: 1026-1033, 2008.

This work is licensed under a Creative Commons Attribution-NonCommercial-NoDerivatives 4.0 International (CC BY-NC-ND 4.0) License. 